\author{
A thesis \\ presented to
}

the Faculty of the Graduate School

at the University of Missouri-Columbia

In Partial Fulfillment

of the Requirements for the Degree

Master of Arts

by

\title{
ELIZAVETA KORSKAIA
}

Dr. Martha Kelly, Thesis Supervisor

MAY 2021 


\section{ACKNOWLEDGEMENTS}

I would like to express my deepest appreciation to my thesis advisor Professor Martha Kelly who guided me through the process of writing this thesis. She provided me with her constant feedback and helped to organize my thoughts. I am extremely grateful to the members of my committee Professor Christy Goldsmith and Professor Timothy Langen. Professor Goldsmith encouraged me to keep writing and presented me with helpful guidelines on working on my thesis. Professor Langen asked necessary questions for further developing my thesis and was very supportive in my process. Many thanks to the professors! 


\section{TABLE OF CONTENTS}

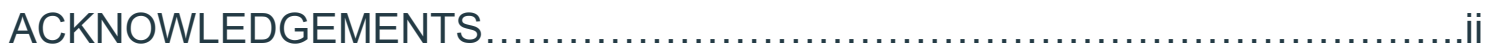

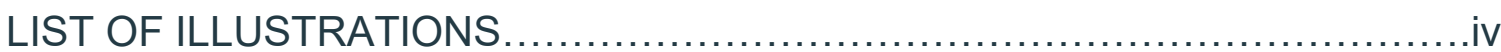

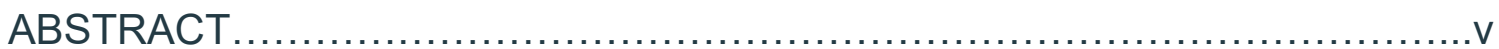

Chapter

I. INTRODUCTION: THE GRAY HOUSE............................... 1-4

II. HISTORICAL OVERVIEW OF DISABILITY IN RUSSIA..................4-8

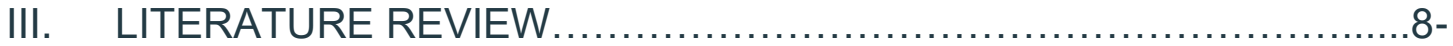

11

The Representation of Disability in Literature

IV. WORLDMAKING: AGENCY AND CHOICE............................11-20

V. TRANSPORTATION TO AND WITHIN THE HOUSE...................20-

27

VI. DISABILITY NARRATIVE: NARRATIVE PERSPECTIVE ...............2731

VII. EPILOGUE. THE ACCEPTANCE OF THE HOUSE: FANFICTION.....3234

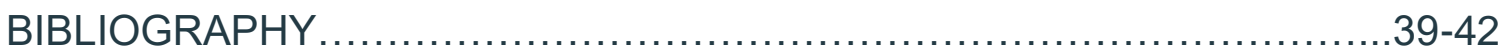




\section{LIST OF ILLUSTRATIONS}

Figure

Page

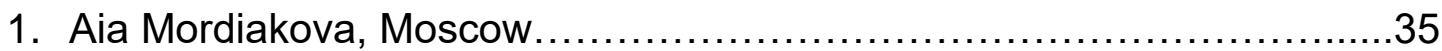

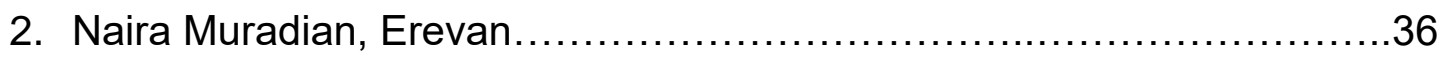

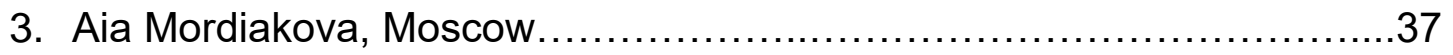

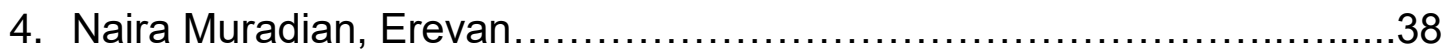




\title{
WORLDMAKING IN THE GRAY HOUSE BY MARIAM PETROSIAN
}

\author{
Elizaveta Korskaia
}

\author{
Dr. Martha Kelly, Master's Thesis Supervisor
}

\begin{abstract}
Disability in narrative often displays negative patterns such as overcoming a disability, exceptional achievements, the association of poverty and crime, and "fixing" someone. Mariam Petrosian breaks these patterns in the depiction of disability in the Russian-speaking world by imagining an orphanage for children with disabilities from their perspective, according to which disability is not an obstacle to be overcome but rather a fact of life. In The Gray House, Petrosian allows her characters to make choices rather than conform to them. By creating rules and reversing norms, they create a distinct world where their agency is incontestable. In my work, I examine the history of disability in Russia and how it reflects the situation in The Gray House. Additionally, I analyze existing scholarship on the depiction of disability in literature connecting theory to the specifics of the novel. In applying Yuri Lotman, I study ways in which characters resemble 18th century Russian citizens, as he presents them: their roles, rules, characteristics and behavior. Applying narrative theory, I integrate Petrosian's use of space and the ability of characters with disabilities to make choices to build the plot of their lives. Furthermore, I discuss shifts in narrative perspective and how these shifts shape the outcome of the characters' plots. Finally, I address the international success of the novel and the importance of its fan base.
\end{abstract}




\section{INTRODUCTION: THE GRAY HOUSE}

The novel The Gray House by Mariam Petrosian carries a remarkable story of its creation. Petrosian was not planning on it ever being published and was creating it only for her family and friends. Beloved characters started living their own lives in the pages of the book, and Petrosian thought that she would write forever. Her friends, however, could not hide such an amazing story from the rest of the world, and brought the book to a publisher who recognized her talent. Petrosian was forced to finish the book in a short time and write the end to a story that was never meant to end. These unexpected circumstances led to some inconsistency in the plot. In spite of this issue, The Gray House became a bestseller in Russia after it came out in 2009 and received prestigious awards such as Russkaia Premia (Russian Award), Bolshaia Kniga (Big Book), Portal and others. The book has been translated into Spanish, Hungarian, Polish, French, English, Czech and Ukrainian, and has gained a huge fan base.

The Gray House is about an institution for children with disabilities and these children's lives. There are two main plot lines, one of them set in the present, and the other in the past. The House consists of groups, and members of each group share specific characteristics such as clothing, appearance and behavior patterns. Members of these groups have nicknames, and even counselors in the House accept theirs. The House has a long history and traditions that are duly followed by its inhabitants. The House is set in opposition 
to "the Outsides," where able-bodied people reign, whereas the House is the kingdom of people with disabilities.

Disability in narrative often displays negative patterns such as overcoming a disability, exceptional achievements, the association of poverty and crime, and "fixing" someone. Mariam Petrosian breaks these patterns in the depiction of disability in the Russian-speaking world by imagining an orphanage for children with disabilities from their perspective, according to which disability is not an obstacle to be overcome but rather a fact of life. In The Gray House, Petrosian allows her characters to make choices rather than conform to them. By creating rules and reversing norms, they create a distinct world where their agency is incontestable.

People with disabilities are often forced to conform to social norms and expectations but in The Gray House this situation is reversed. To differentiate their world and thus their agency, they mark their everyday behaviors with theatricality. Yuri Lotman, a Russian literary scholar of the 20th century, explores behavioral patterns in his work "The Poetics of Everyday Behavior in EighteenthCentury Russian Culture." In his work, he examines the popularity of the plottheatrical construction of someone's biography in the 18th century. He writes that "the eighteenth-century man would select a particular type of behavior for himself, which simplified and elevated his everyday existence according to some ideal" (Lotman 81). The Gray House reflects this idea as well: there are different roles that the inhabitants of the House can play, and many of them share the characteristics of a group and live as a stock character. Other people, however, 
realize that they have the possibility of choice, and start building plots of their own lives. Although they still remain in the limited set of options, they gain more and more agency throughout the novel. The characters who consciously choose to leave the House or to die there establish the agency of people with disabilities in The Gray House.

My work focuses on the analysis of the depiction of disability in Russian literature, specifically in The Gray House by Mariam Petrosian. First, I examine the history of disability in Russia and how it reflects the situation in The Gray House. Additionally, I analyze existing scholarship on the depiction of disability in literature connecting theory to the specifics of the novel. In applying Lotman, I study ways in which characters resemble 18th century Russian citizens, as he presents them: their roles, rules, characteristics and behavior. Applying narrative theory, I integrate Petrosian's use of space and the ability of characters with disabilities to make choices to build the plot of their lives. Furthermore, I discuss shifts in narrative perspective and how these shifts shape the outcome of the characters' plots. Finally, I address the international success of the novel and the importance of its fan base.

The Gray House represents a distinct world, and before examining specific elements of creating a new world in it, it is important to define worldmaking. According to Tom Clark, "each new book, each new commentary, each new piece of criticism is engaged in the process of worldmaking" (Clark 3). In other words, every creative work is a part of or is itself a new world. "Worldmaking" is the creation of a new world, and in fiction, in particular, such a 
world consists of stories, characters, and settings. Some of the features of a new world look exactly like the world we live in while others are completely different not only in their appearance but also in their reasons for existence. The title of the Spanish book edition is translated as "La casa de los otros" (2015)—The House of the Others. In Spanish, even the title suggests another world for the reader.

\section{HISTORICAL OVERVIEW OF DISABILITY IN RUSSIA}

Although Petrosian never names the location of the House, it could easily be located in Russia or in any Post-Soviet country. Some characteristics of these countries-apartment complexes and dying institutions for people with disabilities - are recognizable for a knowledgeable reader. According to larskaiaSmirnova in Disability in Eastern Europe and the Former Soviet Union: History, Policy and Everyday Life, disability in Russia bears "historical legacies of control, segregation and stigma" that are difficult to overcome (larskaia-Smirnova 1). Policies around disability were based on rehabilitation and treatment to return a body to a 'normal' state. Disability is the definition given by an ableist part of society, excluding groups of people from social activity because of the lack of necessary arrangements and conditions. In other words, people are called 'disabled' because they cannot take part in some activities-not because they do not want to, but because they do not have access to them. Before the rise in awareness of critical social issues it was accepted by a majority of able-bodied people to exclude people with disabilities from society by not providing necessary accommodations for them. If there are no accommodations, people with 
disabilities are forced to stay home; and if they stay home, they are not seen, as though they do not exist at all.

\section{Pre-Imperial Russia Before 1700}

In "There are no invalids in the USSR!" Sarah Phillips argues that early literary texts express that those with physical and intellectual disabilities were not socially isolated. Moreover, they were integrated into their communities; they helped with domestic chores and were able to perform easy work such as making baskets or fishing nets, sewing and embroidering. Phillips claims that historians and ethnographers have not systematically studied the question of people with disabilities in pre-imperial Russia, therefore there is no official research, and these findings are based on literary texts and church documents (Phillips 2).

\section{Pre-Soviet Russia 1700-1917}

In the $18^{\text {th }}$ and the $19^{\text {th }}$ centuries life was essentially centered in the village, where people with disabilities were respected and called "wanderers" or "holy fools." They were attached to the Orthodox church and relied on charity.

During the reign of Peter I and Catherine II, asylums and schools for people with disabilities appeared in central Russia, around Saint-Petersburg and Moscow. However, in rural parts, people with disabilities were still connected to the church or sent to monasteries when families wanted to get rid of them. As Phillips mentions, most studies of issues related to disability in the 18 th to early 20 th century Russian Empire focus on people with mental disabilities, but little is 
known about the lives of persons with physical disabilities or sensory disabilities other than blindness (Phillips 6).

\section{Soviet Russia before WWII 1917-1941}

Until the 1920s the term "invalid" did not possess a negative connotation and defined only war-injured. As the Soviet State was rapidly transforming and required a labor force, a guaranteed state assistance to those unable to support themselves due to loss of labor capacity was offered. The Soviet state focused on returning people to their workplaces, so the government established three groups of people with disabilities, and all these categories are still applied in contemporary Russia. The three groups include: 1) people who cannot work or can work in very limited spheres, for example, blind people; 2) people who can work under special conditions and 3) people who are temporarily disabled, for example, after a trauma (Nosenko-Stein 5).

\section{During and after WWII 1941-2000}

World War II united the whole country in order to fight the enemy. War veterans were offered specialized vocational training, job placement, education, and housing. They were also allowed to receive pensions, discounted public transportation passes, equipment for their injuries (prosthetics, special cars, wheelchairs) and pay reduced utilities or rent. The Russian press and literature depicted exceptional invalids who overcame their trauma, and thereby not only became wholesome people but also valuable citizens. The government established special types of housing for people with disabilities, called internaty, 
and divided them into 4 main categories: 1) for elderly and people with disabilities; 2) for people with disabilities only; 3) for "veterans of work"; and 4) for persons diagnosed with psycho-neurological problems. As for children, they were excluded from the ranks of "invalids" until 1967 (Phillips 10).

\section{Contemporary Russia 2000_nowadays}

According to data collected in 2020 by a social issues website Esli Byt' Tochnym (To Be Precise), there are about 12 million disabled people registered in Russia (Esli Byt' Tochnym). More people, however, are unregistered. Disability is the biggest social problem in contemporary Russia, exceeding crime, AIDS and people in jails. An ableist society uses such labels as "useless", "defective" and "burdens to their families" for people with disabilities. They are also discriminated against in jobs, education and social activities. The government passed a law in 2016 about the accessible environment, but careless property owners follow it only partially without actually making buildings accessible. The media occasionally publish stories about people with disabilities, but these stories typically employ stereotypical narratives of overcoming trauma, in an echo of the post-war period.

The historical overview of disability in Russia reveals ongoing negative associations and stereotypes. Institutions for people with disabilities are regarded as places to hide people with disabilities from the rest of society, as though trying to protect not people with disabilities, but able-bodied people. The Gray House is especially valuable not only because it highlights this attitude of able-bodied people towards people with disabilities but also because the House functions 
under the agency of people with disabilities. Petrosian's book responds to common stereotypes about people with disabilities, revealing their unique personalities, fears and dreams. The Gray House demonstrates that people with disabilities are a part of society, as well, and even if they look different, their inner world is as rich, and unique.

\section{LITERATURE REVIEW: THE REPRESENTATION OF DISABILITY IN LITERATURE}

In many literary works, disability plays an important role; however, only recently have scholars begun analyzing the problems of its literary depiction. Characters with disabilities have been opposed to able-bodied characters, as though to expose what is considered "normal" and what is not. Negative connotations, such as poverty, crime or ugliness have been applied to disability in literature. Another stereotype depicted in literary works is that of overcoming disability. The idea of fixing characters has been central in a number of fictional works. The important thing, however, is that these stereotypes have changed and shifted over the years. As society moves toward including individuals regardless of their abilities, race, gender and background, literature discusses disability in a different way. Literary works, such as The Gray House, pay attention to various kinds of disabilities or disability narratives, approaching disability in innovative ways. 
Alice Hall surveys studies of disability in world literature in Literature and Disability (Hall). Hall claims that it is important to rethink familiar narratives about disability, to change the notion of "normal" accepted by society, ethics and aesthetics. For many years, disability was a "symbol of evil, exoticism, weakness or ugliness" (Hall 32). Hall considers the possibility of empathy between ablebodied and disabled people, disability as metaphor in literary genres for key social issues and the intersection of disability studies and feminist, queer and postcolonial studies. Hall frames different types of impairments in a wide range of literary genres including prose (novel and short story), poetry and drama. For my research, Chapters 1,2, 3, and 4 are especially important because they specifically talk about the field of disability studies, disability in literature, and disability in novels.

Another important source is Narrative Prosthesis: Disability and the Dependencies of Discourse by David Mitchell and Sharon Snyder (Mitchell). Mitchell and Snyder examine the meanings assigned to disability in narrative art. "Narrative prosthesis" is a common way of depicting disability in literature by introducing it to the narrative only to remove it later. A narrative prosthesis removes disability from a narrative by "fixing" it, or applies stereotypes in describing disability, such as aesthetic unpleasantness, being abnormal and not corresponding to social expectations. Chapter One provides a theory of the development of the methodological components within disability studies: negative imagery, social realism, new historicism, biographical studies, and transgressive resignifation. The authors discuss the representations of people with disabilities 
in literature and their connections with history. They claim that fiction shapes the attitudes of readers towards people with disabilities: "Readers and viewers and their own personal interpretations of disability inevitably are influenced by their imaginative encounters with disabled people in fictional works" (Mitchell 42). While reading fiction, readers discover the inner world of characters without focusing on what characters with disabilities lack, but rather on what they possess.

The Cambridge Companion to Literature and Disability (Barker), edited by Clare Barker and Stuart Murray also discuss common representations of disability in literature. The book focuses on English-language literature and looks at literary works through a variety of critical approaches. The chapter entitled "The Worldmaking Potential of Contemporary Crip/Queer Literary and Cultural Production" contains the most important information for my work because it studies worldmaking, a key concept I use in my discussion of The Gray House. In this chapter, Robert McRuer examines the similarities of the words "crip" and "queer," and provides examples from literature, visual arts and dance of how people express their "queerness" or "crippleness." He describes how people with disabilities and people from the LGBT community create their own worlds through arts and demonstrate to able-bodied people that it is normal to have a disability. The teenage characters of The Gray House behave like able-bodied teenagers: they fall in love, break up, sneak out at night to drink, listen to music and read books. The novel has gained a huge fandom among able-bodied people, and the characters continue to generate their own community across the 
world, suggesting that stories of people with disabilities can evoke a sense of identification in able-bodied readers.

Although there are a number of sources on disability in world literature, not enough is written about the depiction of disability in Russian literature in particular. It is possible to find studies on specific works; I did not find, however, any scholarly articles or systematic studies of disability in Russian literature. The same problem exists with scholarly sources about The Gray House. Georgii Kubatian and Olga Lebiodushkina have written about the novel but they do not focus on disability. Their articles focus on linguistic aspects or summarize the plot. Book reviews (Margaryan; Taplin) are not helpful either because they examine the atmosphere of the House, characters or magical realism, but not disability. My work is important for ongoing research as I bring together the history of disability in Russia, disability in literature, and disability in The Gray House, applying the theory of Yuri Lotman. My thesis focuses on the agency of people with disabilities in the House through their creation of a unique world inside it.

\section{WORLDMAKING: AGENCY AND CHOICE}

Literature plays an important role in the process of identity formation, and Alice Hall claims literary works to be "capable of taking us through an intense experience of these other-directed impulses and acts" (Hall 5). Literature reflects history and allows readers to have experiences that they would not be able to 
have otherwise. Tom Clark connects literary works with creating storyworlds and says that "literature offers essential insight into the private spheres of others, and... has a greater ability to shape and widen our world views than other discourses that present us only with public and documented faces" (Clark 8). Worldmaking is essential for literature because it allows the reader to peek into someone's life and experience different perspectives. While scholarly literature offers many opportunities to learn about cultures and peoples, literature grants more possibilities for immersion in perspectives not our own. Literary works help readers see their views from another angle, if not change them entirely. Literature can refresh our view of the world and might change feelings towards some aspects of life.

With the rise in awareness of critical social issues, literature about disability has begun to attract more attention. Disability perspectives force ablebodied readers to consider disability in new ways that they might not in their day to day lives. The Gray House is an imaginative description of the lives of young people with disabilities; therefore, for able-bodied people it performs the function of worldmaking. Before The Gray House came out it was unusual in Russian literature to represent disability in narrative as the norm rather than the exception. The question of what is normative is very important for studies of literature and disability, and can be a problematic one to answer. Alice Hall explains that "scholars have critiqued the ways in which fictional characters with disabilities have so often been invoked as straightforward symbols of evil, exoticism, weakness or ugliness" (Hall 32). Such stereotypes present characters 
with disabilities as the Other ${ }^{1}$ : opposed to the norm, which consists of "necessarily white, non-disabled, heterosexual, physically and economically selfsupporting" people (Hall 4). This Otherness highly affected disability narrative, where for some time the "narrative prosthesis" prevailed. David Mitchell and Sharon Snyder describe this as a metaphoric device that engages disability in the narrative but then removes it to restore a sense of normality. Such narratives include cures for disabled characters, superhuman experiences or antagonistic representations to emphasize "tragedy, disruption and deviance" connected with disabilities (Hall 66). Petrosian, however, not only exposes the disabilities of her characters but also frames them as advantages, their keys to the world inside the House. Outside the House, people with disabilities receive pity, therefore, they play a passive role, while in the House, they are able to make their own choices. In The Gray House, Petrosian allows her characters to make choices rather than conform to them. By creating rules and reversing norms, they create a world where their agency is incontestable.

Petrosian's characters agree that they are different from the inhabitants of the Outsides. Moreover, they are proud of it because in the Outsides people with disabilities do not have enough agency. In the House, however, they have enough agency to make rules, therefore, rulemaking is important for The Gray House. Every society follows its own rules, and so does the House. Its inhabitants accept old rules written by people who lived there 50 years earlier. For example, one of the old rules prohibits communication between girls and

\footnotetext{
${ }^{1}$ When capitalized refers to a specific definition in Disability Studies
} 
boys, however, this rule is canceled in the course of the narrative and opens up new opportunities for friendship between the characters. Another important rule forbids talking about the Outsides. It is important to note that many characters are scared and disgusted by any reminders of the Outsides, and this attitude does not change by the end of the novel-some characters decide to not return there at all. On the other hand, some rules are created as the inhabitants of the House grow up. The rules in the House depend largely on the leaders of each group who together constitute the leaders of the House. So when the narration shifts to the past, the reader is met by only two leaders-Mavr and Skull, whereas in the present there are five leaders—one for each group. These leaders create such rules as wearing specific clothes and behaving according to their group number. Such rules sound absurd and do not make sense to outsiders. One of the characters, Smoker, who has not been in the House for a long time, and therefore might still be considered an outsider, says: "The absurdity that is the House was definitely a product of several generations of notquite-right people" (Petrosian 13). He does not want to accept strange rules because he views them as absurd and not applicable to the real world. In The Poetics of Everyday Behavior, Lotman explains possible reasons for such apparent absurdity: he claims that for 18th century Russians forced to conform to European norms to "to behave properly was to behave like a foreigner, that is, in a somewhat artificial manner, according to the norms of somebody else's way of life" (Lotman 69). The inhabitants of the House are required to keep 
differentiating themselves from people of the Outsides, thus, strengthening their agency and making rules that are only applicable to the House.

Strict rules exist not only in the House, but also in each group within it. Birds are obsessed with plants, and the group requires each member to possess a plant to take care of. Birds do embroidery and are in mourning for the leader's long-departed brother (Petrosian 16). Rats are rebellious and hysterical. They cut themselves, cry and fight each other. Their group's requirement is to possess a knife or a blade (Petrosian 15). The Pheasants want to be perfect and not stand out from each other. From the beginning, Smoker breaks these rules by wearing bright red sneakers, and by smoking cigarettes, earning himself his nickname. Some people simply cannot believe their eyes and say that a smoking Pheasant is weird. By distinguishing himself from the 1st, Smoker becomes an outcast. When he moves into the 4 th, however, he remains an outcast because he simply cannot follow rules that do not make sense to him. Smoker has not been living in the House his whole life, so he sees it as an outsider and is able to critique people's actions. He thinks that "one day they became so frightfully bored that they compiled the script of the Game and vowed to never deviate from it under any circumstances. For everyone his role and everyone in his place" (Petrosian 84). Smoker analyzes the rules of the Game as Lotman analyzes the 18 th century society. He sees that there are assigned roles, expected outcomes, and strict traditions. It is possible, however, to choose one's own behavior, thus demonstrating agency within a group and in the House. 
Another category of making a new world in The Gray House is

nicknaming. Petrosian's characters do not call each other by their proper names, and probably do not even know them. They call each other by nicknames, in most cases based on their appearance (Tubby, Humpback, Bubble), but sometimes on their actions, too (Smoker, Professor, Crybaby). People receive their nicknames the first day they arrive at the House, as a kind of initiation, but it is possible to change them later. For example, Grasshopper becomes Sphinx when he is older, and Sportsman becomes Black. Characters do not have a choice in choosing a nickname-they just stick to a person; however, they choose a group to belong to. These groups can be understood through Lotman's notion of the "a complex system of behavioral genres" (Lotman 81). According to Lotman, this system divides aspects of everyday life into "units of performance," and the transition from one unit to another requires a change of behavior (Lotman 81). Similarly, in the House transferring from one group to another requires accepting the rules of the new group. The inhabitants of each group within the House share the same features and thus bear group nicknames, too: Group 1-“Pheasants," Group 2-"Rats," Group 3-"Birds," Group 6-“Hounds," and "Group 4"2 (Petrosian Appendix). The last group is unique in not having a name. The members of this group came together as outsiders from other groups, and this is why they are marked as special. Pheasants are also different from the rest of groups not only because they are the quietest ones (so-called nerds), but

\footnotetext{
${ }^{2}$ Group 5 does not exist because the numeration goes by room numbers, and rooms 5 and 6 are both occupied by Hounds.
} 
also because they are the only group completely consisting of people in wheelchairs. People who are not able to walk, however, live in Group 4, too, because they have chosen to do so. This possibility of choice brings to mind Lotman's concept of the "stock character," according to which there are different roles characters can play. Lotman explains the "stock character" as a set of typical roles the 18th century Russian citizen could choose (Lotman 81 ). In the House, when the residents choose a group, they submit to its rules and associated characteristics. Many residents spend their entire lives living in one group and playing one role. Others, however, realize that they can play any role, thus strengthening their agency in the House.

Not only do people in the House receive nicknames, but places do, too. For example, a hospital wing is the Sepulcher; a room for punishment is the Cage; a sort of a cafe or a lounge is the Coffeepot; the place in between the boys' and girls' wings is the Crossroads. The most terrifying place, however, is the Outsides. It is not safe, there are different rules which people from the House do not know; it is inhabited by able-bodied people who seem a threat. The only real name the reader finds out over the course of narrative is Smoker-Eric Zimmerman. Smoker does not really belong to the House, and understands that this world has nothing to do with the real world. For him, it is a game, while for other people nicknames are a passcode to the unique world of the House.

While each group within the House shares certain characteristics, clothing also plays an important role in the self-identification of the characters and helps to create "stock characters." People wear distinctive clothing both because they 
believe it makes them exceptional and gives them a sense of belonging. They belong to the House because they accept rules of dressing and behavior, but each of the characters is unique in the details. They are united in groups but they possess individual characteristics inside a group. For the characters, every day is like a fashion show; they evaluate each other not only on the basis of their character, but also on the basis of their appearance. They exchange clothes, jewelry and accessories to show off in front of each other, as anyone might. In the outside world, as in the House, people wear uniforms or costumes to make themselves visible for the rest of the population or to celebrate an event. The inhabitants of the House, however, do not see costumes or uniforms as only clothing for a holiday or special occasion. They make every day a holiday and show their agency by wearing special clothes on an everyday basis.

According to Yuri Lotman, theatrical costumes imitate real life, thus they are not real. They seem real, but to be seen from the stage by the audience, they need to be more detailed and prominent than the real prototype (Lotman 71). This notion echoes in Smoker's calling Hounds "bikers without their bikes." They wear overstated leather and chains, look like bikers, but are not bikers. While describing his group, he says: "Our table is in black and white. White shirts, black pants. White plates on black trays. Black trays on white tablecloth" (Petrosian 15). There is a rule of black-and-white color contrast in the Pheasants' group, so of course when Smoker puts on his bright red sneakers, he becomes too visible for them. Rats are remarkable, and their rule for clothing is simple-bright and loud. Smoker describes their table as "the rowdiest and most colorful. Dyed 
mullets, sunglasses, and beads. Thumping earphones. Rats, a cross between punks and clowns" (Petrosian 15). He sees what they do not see, he even pities them for trying so hard to be different from the rest of the groups. It is ironic that Smoker's bright sneakers are a part of a similar protest, but he does not notice this controversy. He starts accepting the House and its inhabitants as they are, but further events scare him, and he then rejects them. The House is a big stage for young people to perform on an everyday basis. Petrosian describes the characters of The Gray House in a unique way-they have their theatrical identities that people with disabilities in many narratives do not get to have. By acting and being theatrical, characters gain more and more agency, proving that they rule in the House.

Characters choose their roles and perform. On the one hand, they perform in front of each other to demonstrate that they belong to the House and are ready to accept every strange rule. On the other hand, they perform in front of the inhabitants of the Outsides. In order to maintain their agency, they are required to be theatrical. For example, when a new counselor comes to Group 4, she expects to see disabled and probably mentally unstable children because of the stereotypes people with disabilities are assigned in the Outsides. Therefore, characters assume that they not only have to show her that they are unstable, but also that they are dangerous and powerful. For an able-bodied reader it might come as a surprise-usually people with disabilities are not regarded as threatening or strong enough to be afraid of. Characters show the new counselor that in Room 4, they can do whatever they want with her, and even though she is 
able-bodied, she does not have agency and power there: they do. Such behavior recalls theater. Actions, costumes and facial expressions are more prominent on the stage so people in the audience can see and understand a play.

Rulemaking, nicknaming and clothing constitute the unique world of The Gray House. Each group in the House shares similar characteristics or is forced to do so. Many narratives disregard disability or make it the most important feature of a character. Petrosian breaks such narrative patterns by giving her characters distinct identities which do not depend on their disability. While ablebodied rebels are frequently seen in literature, not many disabled rebels act in their own interests. Characters with disabilities in The Gray House make their own decisions, break rules and create new ones, and prove themselves as remarkable as more normative able-bodied heroes. Characters who choose to return to the Outsides selecting their own plot strengthen their agency and demonstrate to the inhabitants of the Outsides that they are not passive followers.

\section{TRANSPORTATION TO AND WITHIN THE HOUSE}

The House is a mysterious place with strange rules, unique inhabitants and dangerous spaces. Not only are there two main spaces connecting the world of able-bodied and disabled —-the Outsides and the House; there are also differentiated spaces within the House. Characters explore all spaces within the House, but the Outsides remains untouchable. Although some characters 
occasionally go to the Outsides to trade or explore, most of them are scared of it. The Outsides' main function is to expose the opposition between the two worlds. Petrosian uses space in her novel to enable some characters to take transformational journeys, where they choose their own plot out of limited options. By choosing the outcome of their lives themselves, they demonstrate their agency not only in the House but also in the Outsides.

After characters choose their roles, they are able to develop a plot. In Lotman's model, "the next stage in the evolution of a poetics of behavior may be characterized as the transition from stock role to plot" (Lotman 85). According to Lotman, activities assigned by a stock role ultimately lead to a specific "finale" (Lotman 85). As every theatrical performance ends with a final scene, characters' plots in the House end with graduation from the House. There are two options for the characters: to leave the House and build a life in the Outsides or to never leave the House physically: in other words, to commit suicide. Therefore, they think carefully about the future and prepare for the outcome of their lives. Such a process, according to Lotman, is called "consciously regulated activity" (Lotman 94). The actions of the characters stop being improvised and spontaneous and become a carefully considered act. The characters of the House have only two options, but it is still possible for them to choose. Even with this limited set of options, characters make a choice themselves, and establish their agency in The Gray House.

The first choice is the Outsides, and for people with disabilities graduating from a specialized institution, it is a difficult decision. Petrosian begins her novel 
by contrasting the Outsides to the House. A first impression can never be made twice, and the desire of the reader to dive deeper into a storyworld may depend on the opening paragraphs. David Herman explains the importance of story beginnings in Basic Elements of Narrative and notes that it is possible to understand such details as characters' personalities, settings, realities and attitudes about a story by reading only its beginning (Herman 112). The opening of The Gray House is highly marked by the opposition of two realities: the House and the Outsides. A close reading of the opening paragraphs facilitates an analysis of the relationship between these two spaces. The "Outsiders"' biased attitude towards the House becomes clear at the end of the paragraph and will be noticeable through the whole novel. Petrosian invites the reader into the world of the House by describing it and the area around it:

The House sits on the outskirts of the town. The neighborhood is called the Comb. The long buildings of the projects here are arranged in jagged rows, with empty cement squares between them - the intended playgrounds for the young Combers. The teeth of the comb are white. They stare with many eyes and they all look just the same...

In the no-man's-land between the two worlds-that of the teeth and that of the dumps-is the House. They call it Gray House. It is old, closer in age to the dumps, the graveyards of its contemporaries. It stands alone, as the other houses shun it, and it doesn't look like a tooth, since it is not struggling upward...

Nobody likes Gray House. No one would admit it openly, but the inhabitants of the Comb would rather not have it in their neighborhood. They would rather it didn't exist at all (Petrosian 5).

Nothing in this beginning points to the characters' having disabilities; however, from the first sentence the reader sees that the House is isolated. 
Petrosian first describes the House as being far from the center of the city, displaced to the outskirts, much like people with disabilities in Russian society. Then she mentions "the Comb"-apartment complexes where a special group of people nicknamed Combers live and play. By giving a nickname to the inhabitants of the complexes she compares them with the inhabitants of the House, who are not yet mentioned. The complexes resemble each other, as do the people who live inside, in the narrator's opinion. Furthermore, the narrator presents a dreary description of the House, causing it to sound old and in poor condition. The House stands out from the rest of the area around it because it is relatively low and is surrounded by tall apartment complexes. It stands apart from these complexes, which is a clear allegory for people living inside versus outside the House. There are two worlds which do not intersect and which prefer to be separated. The last paragraph of the beginning is intriguing. Petrosian writes that the Combers do not love the House, but they are silent about it. The reader does not yet understand that there are people with disabilities in the House, but it is possible to see the attitude of the outside world towards them already. Such people are not desirable for the rest of society, and they would prefer that the House with its inhabitants did not exist at all.

The Gray House, however, is not about the rest of society, but rather about the people of the House, their actions, beliefs, dreams, and plans. Petrosian introduces the House and its inhabitants as outcasts but then presents the world from their perspective. In a remarkable way, Petrosian 
uses her story beginning set in the outside world to evoke a narrative of an alternative world. Petrosian antagonizes not people with disabilities as many other writers have in the past, but rather a society that makes normal life inaccessible for people with disabilities by not accepting them as equals.

Another outcome for characters' lives is staying in the House forever. The inhabitants of the House arrive there from the Outsides. Although Petrosian does not tell all characters' stories, it is implied that they arrive at the House at some point. The House not only welcomes them but also changes how they feel about themselves and the Outsides. In Basic Elements of Narrative, David Herman quotes Richard Gerrig, who identifies six key elements of movement in storyworlds. He talks about transportation to and from a storyworld and explains what happens at each stage of a movement. Gerrig details:

1. Someone ("the traveller") is transported

2. By some means of transportation

3. As a result of performing certain actions

4. The traveler goes some distance from his or her world of origin

5. Which makes some aspects of the world of origin inaccessible

6. The traveler returns to the world of origin, somewhat changed by the journey (qtd. in Herman 119).

These six elements correspond to the movements of characters in The Gray House, and Grasshopper is a perfect character for applying Gerrig's theory. The six elements Gerrig describes help Grasshopper accept himself and stop being worried about society's attitude towards his disability. His journey begins and ends in the Outsides: however, he becomes a different person by the time he returns to the Outsides. In keeping with the first movement by Gerrig, Grasshopper is brought to the House by his mother, and Petrosian makes it clear 
that it was not his idea. She describes the white blazer Grasshopper is wearing in the heat that indicates the desire of his mother to hide his lack of arms. She wants her son to be hidden from the rest of society. Next, Gerrig talks about means of transportation, and in Grasshopper's case it is the bus and a long walk by foot. Petrosian gives a detailed description of the walk to the House-the heaviness of the suitcase the mother is carrying, the awful heat, Grasshopper's tiredness and his unwillingness to go to an unknown place. The third point by Gerrig introduces elements of cause and consequence. Grasshopper's cause is lack of arms and the inability of his mother to deal with this fact. She is not ready to meet the physical and mental obstacles set up by society. As a consequence, Grasshopper is transported to the House, where he is supposed to live among people presumably like him. At first, he does not identify with them and describes them as "assembled from pieces." In the course of his journey, however, he accepts these people and becomes one of them. Grasshopper separates himself from the Outsides-his world of origin. There is not a big physical distance between the two worlds-it is enough to cross the dumps to enter the Outsides, but the psychological difference based on the bias society holds against the House is significant. In the House, Grasshopper can finally be himself and stop hiding his lack of arms under clothes: many inhabitants have a disability in this place. The Outsides becomes inaccessible-not because Grasshopper wants to go there and cannot, but because he does not need it anymore. He assimilates to life in the House and forgets his problems on the other side. After graduation, Grasshopper returns to the Outsides. He is ready to meet its challenges because 
his will for life is stronger than his fear of able-bodied people. For the rest of society it might seem that Grasshopper returns to the Outsides still the samedisabled and not used to living outside of an institution, however, he chooses to leave the House himself. Grasshopper improvises in his assigned role, although it causes him great pain-all his friends take the easier path and never leave the House.

Movement, however, exists not only between the House and the Outsides. Much of the novel's plot consists of movements within the House. There are such spaces as the Forest, the Cage, the Sepulcher, the Coffeepot and the Crossroads-each having a distinct name and each requiring specific actions to get there. The Sepulcher is the scariest place for the inhabitants of the House inside of it. For able-bodied people, it is just a hospital wing, but for people with disabilities this place means that they might never return from it. The inhabitants of the House call people working in the Sepulcher "Spiders," as though these workers use their web to take people there against their will. The point Gerrig makes by examining these six movements is that a traveler comes back changed from a journey. People of the House often come back changed from the Sepulcher-Grasshopper receives prosthetics and meets friends; Lord is taken away to a city mental hospital; Red recovers and becomes a leader of the Birds group. All these characters' lives change after they spend some time in the Sepulcher. The Cage-a punishment cell—on the one hand, is terrifying too, because it represents isolation and loneliness. The characters, however, find ways to reverse the true meaning of it by taking books, snacks, cigarettes and 
games there. Years spent in the House teach them to enjoy and appreciate a lot of things, so they make the Cage a kind of vacation. They return back from the Cage well-rested and ready to fight their way through in the House. Each of these places requires specific actions, and characters know what they have to do to get there. They sustain their agency in the House by exploring space and making conscious choices.

\section{DISABILITY NARRATIVE: NARRATIVE PERSPECTIVE \& AGENCY}

Through examining the history of disability in Russia and the existing scholarship on disability in literature, it is possible to compare common approaches to the approach Petrosian takes in The Gray House. Snyder and Mitchell suggest that "the desire to impose closure on a narrative is a feature of many narratives of disability." They add that "recent narrative work in disability studies examines formulas for their drive toward the solution of curing and killing of disabled characters" (Hall 178). Compared to common narratives about disability, Petrosian does not try to cure her characters. She asks the reader to accept them as they are, and love them for their personality. Her characters tell stories, knit and sew, sing, dance, and read. They fall in love, break up, secretly drink and smoke cigarettes. Their lives are just like any other teenagers', the difference lies in some characters' disabilities. Some characters do die in the end of the book, but Petrosian does this not to remove them from the narrative. She pictures their choice between the Outsides and the House, and she permits 
some of her characters with disabilities to live. Characters who make conscious choices about staying in the House or going back into the outsides establish the agency of people with disabilities in the novel. The difficulty of these choices is represented in particular by multiple shifts in narrative perspective throughout the course of the novel.

The Gray House includes chapters from first- and third-person narrative perspectives. According to Jesse Matz, who studies narrative perspectives, "third-person narrative enables neutrality and objectivity, and therefore, better accuracy and understanding" (Matz 153). Snyder and Mitchell argue that "the characteristic intimacy with disabled characters in literature, achieved through first-person narrative perspectives allows a unique space for contemplating the complexity of physical and cognitive differences" (qtd in Hall 5). First-person narration reflects the feelings of characters and how these feelings affect their actions. First-person narration engages about $60 \%$ of the book, and third-person narration-about $40 \%$. The Gray House consists of three books, and the percentage of first- and third-person narration varies greatly between them. The following table presents the percentage of first and third-person narratives in each book:

Table 1. Percentage of First- and Third-Person Narration in The Gray House

\begin{tabular}{|l|l|l|}
\hline Book number & First-person narration & $\begin{array}{l}\text { Third-person } \\
\text { narration }\end{array}$ \\
\hline Book One & $58 \%$ & $42 \%$ \\
\hline Book Two & $36 \%$ & $64 \%$ \\
\hline Book Three & $81 \%$ & $19 \%$ \\
\hline
\end{tabular}




\begin{tabular}{|l|l|l|}
\hline Epilogue & $50 \%$ & $50 \%$ \\
\hline
\end{tabular}

The percentage between first- and third-person narration in Book One does not display a significant difference. First-person narration is represented by Smoker and demonstrates his subjective attitude towards the House. He gradually becomes aware of the rules there and criticizes them. Third-person narration mostly represents Grasshopper's point of view, and includes his memories of the past after his arrival at the House. The shifts between first- and third-person narration are balanced and regular. They perform the function of admitting the reader into the world of the House, including via subjective experience, and setting the scene for major events.

In Book Two, third-person narration prevails. There are regular shifts between characters, and new characters, such as Ralf, Ginger, Vulture and Mermaid are introduced. In this book, third-person narration represents how the world of the House functions, as well as the diversity among its inhabitants. According to Wayne C. Booth, third-person narration allows more depth in the exploration of a narrative world because "it depends less on the particular perspective taken than on the narration's approach to the representation of consciousness" (qtd. In Matz 156). Third-person narration is not only more objective, but it also presents a reader with details that would be inaccessible for a first-person narrator. In Book Two the reader becomes aware of people from different groups of the House and even shares in the experiences of counselors, and the headmaster. Book Two also provides details from everyday life of characters and movement between spaces. Moreover, Petrosian demonstrates 
how complex the relationships between people and the House are, as well as relationships among people there.

Book Three demonstrates a significant difference between first- and thirdperson narration. In this book, the reader looks at the world through the eyes of Smoker and Grasshopper, and almost all events happen in the present. The third book is set up to be the most difficult psychologically since this is the book where characters make their conscious choices to either commit suicide or be released to the Outsides. It makes sense, therefore, that Petrosian uses first-person narration for the considerable part of it. First-person narration emphasizes the inner experience of characters including the transformation they experience in the course of the events. Recalling Lotman's "consciously regulated activity," it is possible to say that Book Three is a key moment for characters to demonstrate their agency in the House by making choices. All previous actions ultimately lead to the final goal which differs from character to character. Book Three also manifests the contrast between the experiences of Smoker and Grasshopper. Smoker is shocked by the suicides of his roommates and he does not understand why the Outsides for them is worse than the House. He has never considered not leaving the House, and he is ready to return to his 'normal' life. Grasshopper, however, is confronted by a hard choice-all his friends who become his family over the years choose suicide over the Outsides, and he can either join or betray them. He chooses life and the Outsides, but it is still hard for him to let his friends go forever. 
The Epilogue is important for understanding narrative modes, too. It includes stories of characters who survive and grow up after graduation from the House. As many familiar characters die in the House, the Epilogue consists of the stories of Needle, Hybrid, Horse, Red, Grasshopper, Smoker's father, and Smoker himself-all of whom survive. Some people have founded a community in the woods, where they live their whole life as though trying to recreate the House. Smoker becomes a famous artist who paints the House and events that happened there. Grasshopper works as a child psychologist and adopts a blind child in whom he seems to see Blind, and whom he wishes to give a better life than Blind had. The stories of these characters demonstrate the power of their choices in the House, and their consequences.

In each book of The Gray House, first- and third-person narration play their specific roles. Almost equal usage of first- and third-person narration in Book One sets the scene and invites the reader into the world of the House. Prevailing third-person narration in Book Two demonstrates how this world works, and what rules it follows. It also introduces the diversity across characters. Book Three with predominant first-person narration lets the reader experience the inner feeling of the characters before an important decision they have to make. The shift in narrative perspective makes it possible for able-bodied readers to empathize with characters with disabilities as the ability to make choices excludes pity for them but confirms their agency. 


\section{EPILOGUE. THE ACCEPTANCE OF THE HOUSE: FANFICTION}

Not only has The Gray House received awards and been translated into several languages: it has also gained a wide fan base all over the world. People depict characters of the book, write fan fiction and even make movies. In 2020, a movie The Inside of Violence was released by a director from Perm, Russia, although Petrosian has repeatedly announced that she is against the creation of a movie about her characters. As mentioned in the introduction, she never wanted to share her characters with the rest of the world. Although The Inside of Violence claims to be based on the motifs of The Gray House, the Internet community has speculated about it a great deal and refers to it as the only movie about the House. Petrosian published her official reaction to this issue, saying that she was never asked for the permission to make this movie, and she does not want it to be associated with its story of the House. She loves her fans, but she says that this movie is not just a fan-made movie —it is created by a real director using budget and equipment but without any rights. This is a controversial situation because on the one hand, fans are excited about seeing their favorite characters on the screen, but on the other hand, Petrosian wants to control fandom, which is almost impossible.

For the new edition of The Gray House, Petrosian organized an artistic contest. The best illustrations of her characters were included in the new edition of her book. I have included four of these works in my thesis to demonstrate how serious fans perceive the inhabitants of the House. For example, in Image 1, 
anyone who has read The Gray House is able to recognize Smoker in a wheelchair wearing the red sneakers that get him into so much trouble. Next to him is probably Black, since he does not seem to have any visible disabilities, and his hair is blonde. Images 2 and 3 depict Grasshopper, since he is bold and wears prosthetic arms. In Image 3, however, the adult figure could represent Moose or Ralf, since after the death of Moose, Ralf becomes his substitute for Grasshopper. Image 4 portrays one of the most remarkable characters in the House-Tabaki. He is wearing layers of clothes and a lot of hand-made jewelry. He hates clocks, so he is trying to get rid of the one in the picture. These are only four images: however, there are many more of them on websites devoted to The Gray House. Fans write their own fiction about the characters of the House, trying to fill in the gaps between the different parts of the narrative. They argue with each other about the origin of the House and its rules.

Scholars (Kubatian; Lebiodushkina) also have been trying to understand why The Gray House became popular so quickly, and what it is in the novel that makes it accessible and attractive to such a wide range of readers. The language is rather simple, and sometimes it recalls Internet chat culture; however, it is not language that is most important for the novel. According to my research, The Gray House is unique because it represents a world created by people with disabilities and shaped by their choices. It is also possible to apply Yuri Lotman's theory about theatricality in everyday behavior to The Gray House in order to demonstrate the importance of the agency of people with disabilities. Characters establish their agency in the House by creating their own rules, rather than 
complying to them in the Outsides. They play specific roles, gradually, however, becoming aware of available choices. Although many of them follow the common plot, some of them make conscious choices and leave the House. Fans all over the world identify with their agency, their ability to make choices and the difficulty of those choices. The personalities of the characters are so strong and remarkable that able-bodied fans focus on them rather than on the fact of disability. Fans also seem to demonstrate that the rules of the House are applicable not only to the House. They make up nicknames and wear clothes like their favorite characters do. It is impossible to recreate spaces from the House in the Outsides where the fans live, but writing stories about these places to reconstruct at least fictional spaces.

The debates on the Internet have not yet died down—nearly 11 years after the first publication of the novel. Publishers and magazines invite Petrosian for interviews and anticipate her subsequent books. For not being a public person, she responds well-she is sincere about her characters, and tries to share everything she has imagined but never written about them. She is happy about fans and their art, but she has not accepted any further official offers. She says that she sold her characters, and this is enough. Many people remain indifferent after reading The Gray House, but its fans like to say, "If you liked this book, the House has accepted you." 


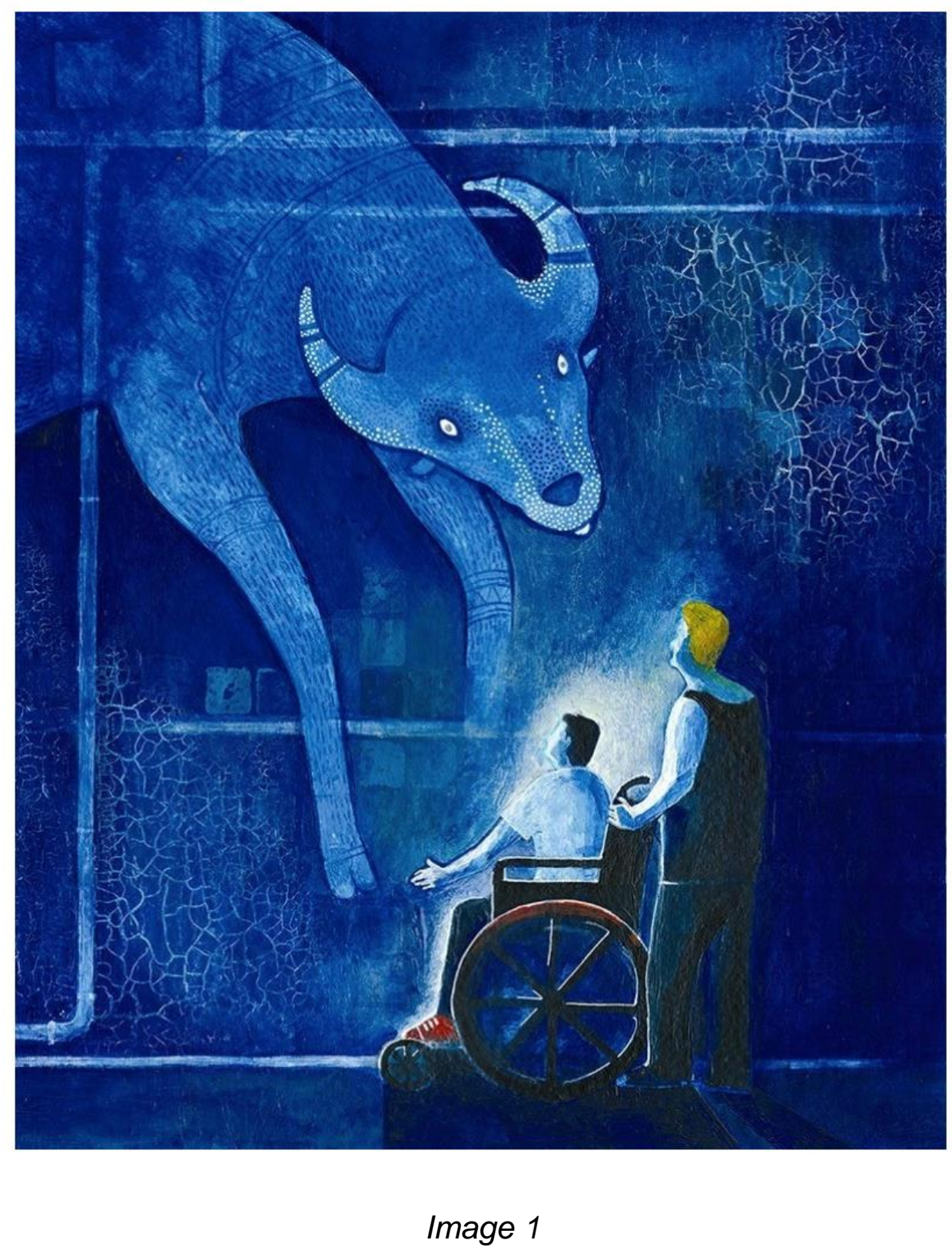




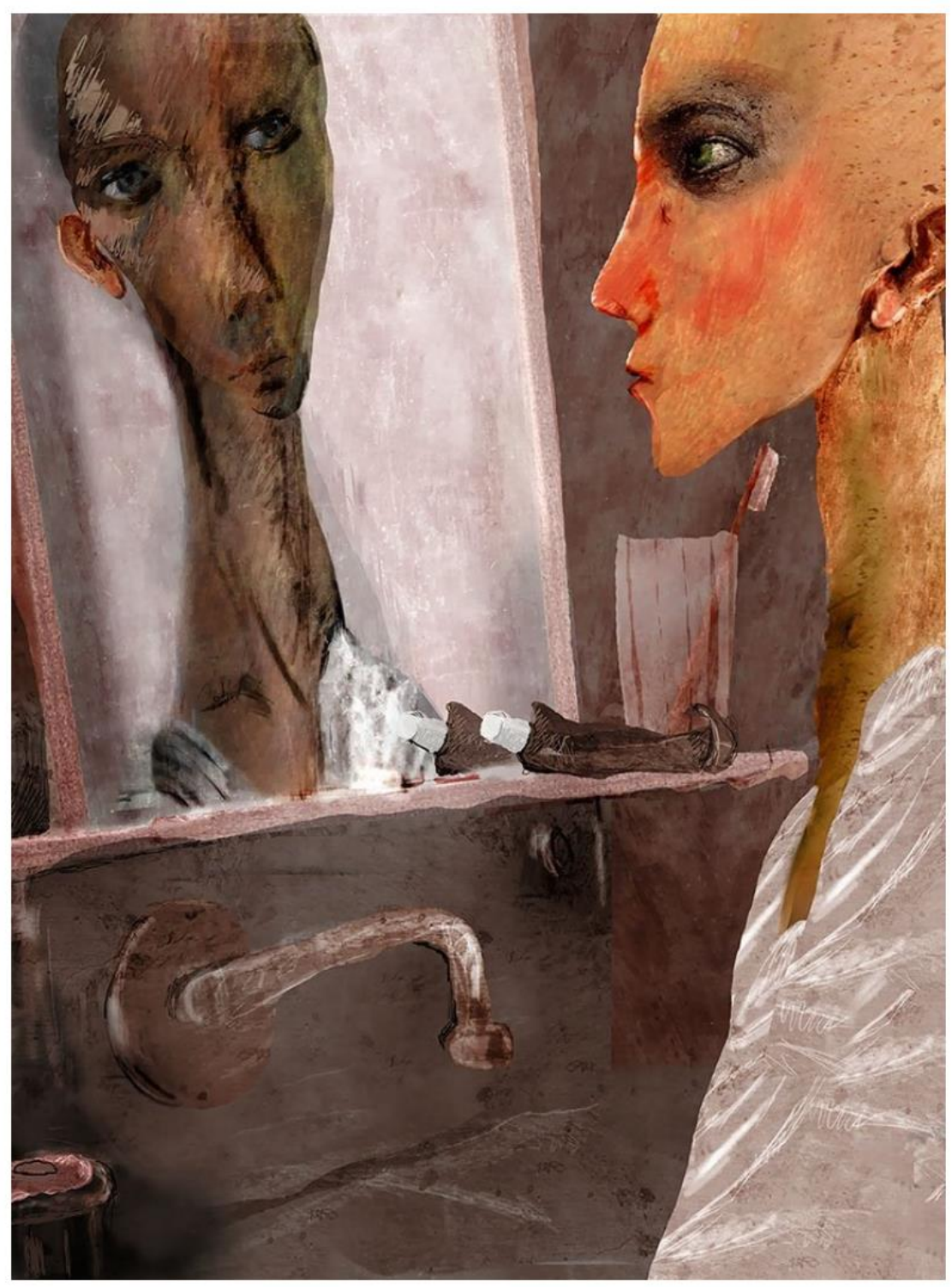

Image 2 


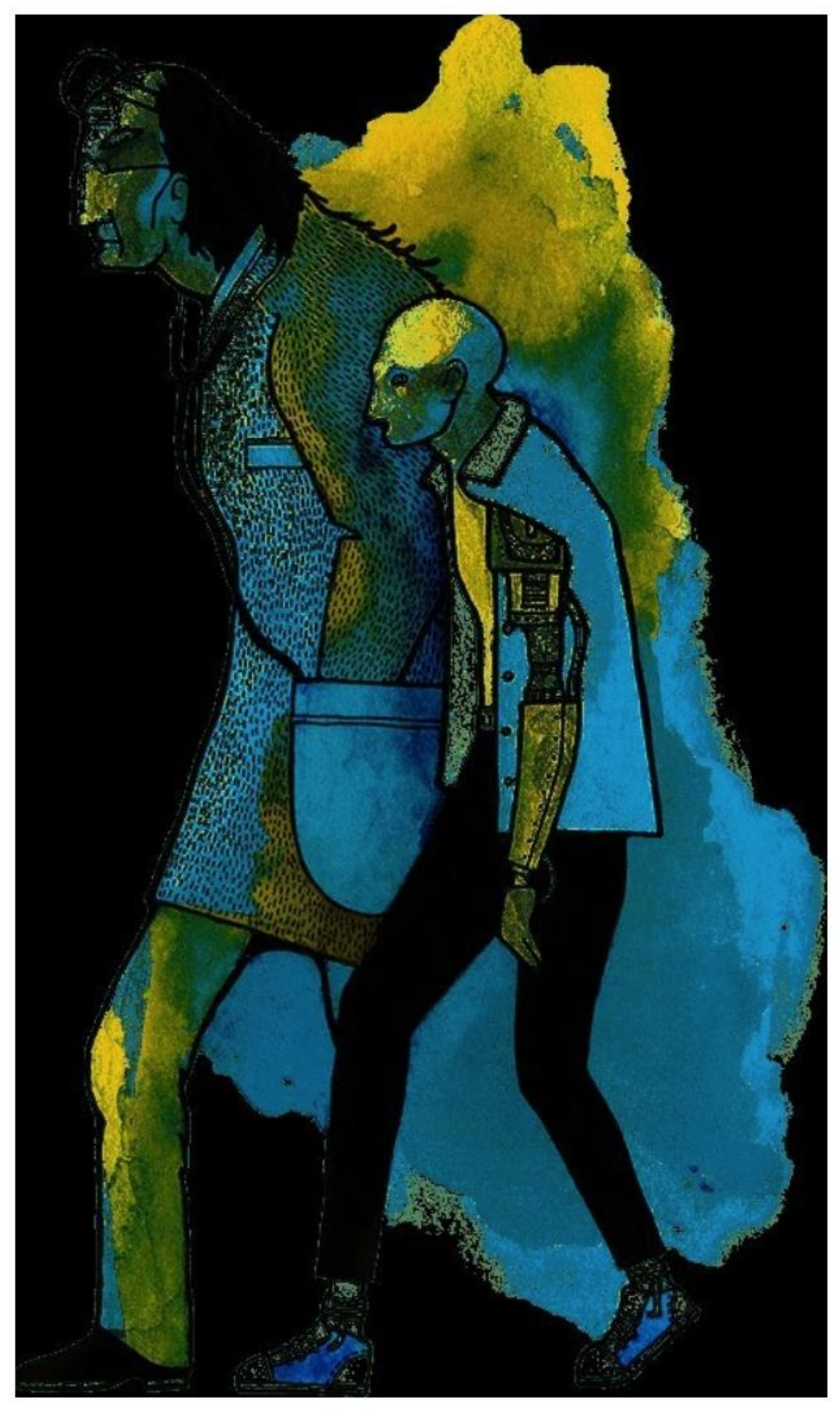

Image 3 


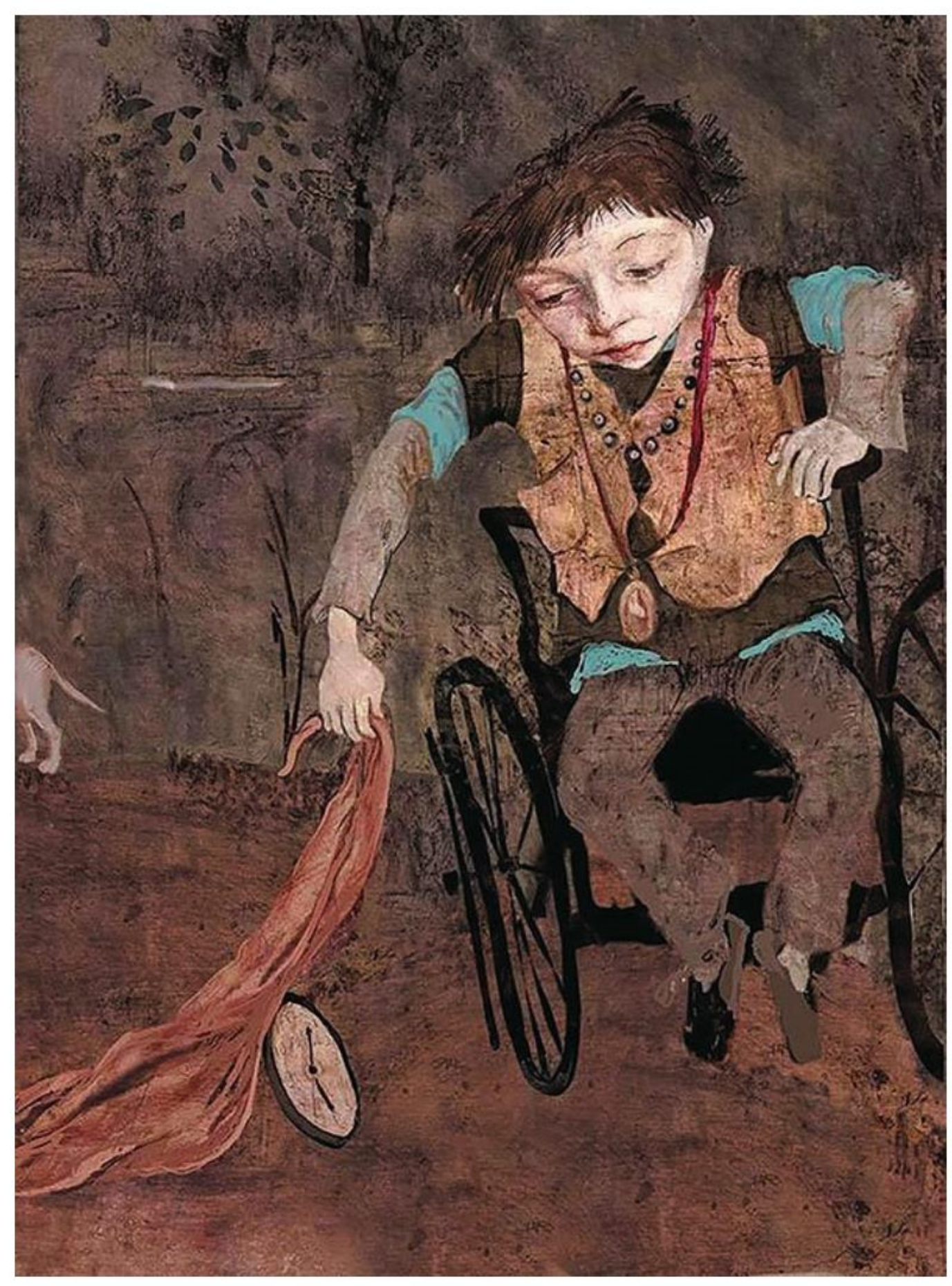

Image 4 


\section{BIBLIOGRAPHY}

1. Bérubé, Michael. Disability and Narrative. PMLA, vol. 120, no. 2, 2005, pp. $568-576$.

2. Clark, Tom, Emily Finlay, and Philippa Kelly. Worldmaking: Literature, Language, Culture. Amsterdam: John Benjamins Publishing Company, 2017.

3. Esli Byt Tochnym (If You Are Precise). https://tochno.st/problems/disability

4. Fludernik, Monica. "Identity/alterity." Narrative, edited by David Herman, Cambridge University Press, 2007, pp. 260-274.

5. Herman, David. "Time, Space, and Narrative Worlds." Teaching Narrative Theory, edited by David Herman, Brian McHale, and James Phelan, MLA, 2010, pp. 123-137.

6. Herman, David. "The Third Element; or, How to Build a Storyworld." Basic Elements of Narrative, edited by David Herman, Wiley, 2011, pp. 105137.

7. Hall, Alice. Literature and Disability.Taylor \& Francis, 2015.

8. Hall, A. "Disability and Modern Fiction: Charting new territory." Disability and Modern Fiction: Faulkner, Morrison, Coetzee and the Nobel Prize for Literature, edited by A. Hall, Palgrave Macmillan, 2014, pp. 1-20.

9. Hunt, Lynn. Inventing Human Rights: A History. W.W. Norton \& Company, 2008. 
10. Kubatian, Georgii. Vnesistemnaia edinitsa. Druzhba Narodov. Vol.4, 2011.https://magazines.gorky.media/druzhba/2011/4/vnesistemnayaedinicza.html

11. Kudlick, Catherine J. Disability History, Power, and Rethinking the Idea of "The Other". PMLA, vol. 120, no. 2, 2005, pp. 557-561.

12. Lebiodushkina, Olga. Interview with Mariam Petrosian. Pervoe sentiabria, 2010 https://ps.1sept.ru/article.php?ID=201000128

13. Lotman, Yurii. "The Poetics of Everyday Behaviour in EighteenthCentury Russian Culture." The Semiotics of Russian cultural history: essays, Cornell University Press, 1985, pp. 67-94.

14. Margaryan, Lilit. "The Eternal Magic of Mariam Petrosyan's Gray House." EVN report, 14 Oct. 2018. https://www.evnreport.com/arts-and-culture/theeternal-magic-of-mariam-petrosyan-s-gray-house

15. Matz, Jesse. "Perspective." Teaching Narrative Theory, edited by David Herman, Brian McHale, and James Phelan, MLA, 2010, pp. 151-165.

16. McCagg, William O, and Lewis Siegelbaum. The Disabled in the Soviet Union: Past and Present, Theory and Practice. University of Pittsburgh Press, 2009.

17. McRuer, Robert. "The World—Making Potential of Contemporary Crip/Queer Literary and Cultural Production." The Cambridge Companion to Literature and Disability, edited by Clare Barker and Stuart Murray, Cambridge University Press, 2018, pp. 139-155. 
18. Mitchell, David T, and Sharon L. Snyder. "Introduction and chapter one."Narrative Prosthesis: Disability and the Dependencies of Discourse, edited by David T. Mitchell and L. Snyder, University of Michigan Press, 2014, pp. 1-45.

19. Murray, Stuart. "The Ambiguities of Inclusion." The Cambridge Companion to Literature and Disability, edited by Clare Barker and Stuart Murray, Cambridge University Press, 2018, pp. 90-104.

20. Nosenko—Stein, Elena. "They fear us because we are Other: attitudes towards disabled people in today's Russia." Salud Colectiva, vol.13, no. 2, 2017, pp. 157-170.

21. Petrosian, Mariam, and Yuri Machkasov. The Gray House. Amazon crossing, 2017.

22. Petrosian, Mariam. Dom v Kotorom. Laivbuk, 2016. Internet Resource.

23. Petrosian, Mariam, and Xènia Dyakonova. La Casa de los Otros. Edhasa, 2015. Internet Resource.

24. Phillips, Sarah. There are no invalids in the USSR!: A missing Soviet chapter in the new disability history. Disability Studies Quarterly, vol. 29, no. 3, 2009.

25. Rasell, Michael, and Elena Iarskaia—Smirnova. "Conceptualising disability in Eastern Europe and the former Soviet Union." Disability in Eastern Europe and the Former Soviet Union: History, Policy and Everyday Life, edited by Michael Rasell and Elena larskaia-Smirnova, Routledge, 2014, pp. $1-18$. 
26. Shklovsky, Victor. "Art as a device." O teorii Prozy, edited by Victor Shklovsky, Moskva: Federatsyia, 1929, pp. 7-23.

27. Taplin, Phoebe. "The Gray House by Mariam Petrosyan review - a cult magical realist saga." The Guardian, 14 May, 2017. https://www.theguardian.com/books/2017/may/13/the-gray-house-by$\underline{\text { mariam-petrosyan-review }}$ 